\title{
Commentary: The future of heart valve surgery: Transcutaneous aortic valve replacement and beyond
}

\author{
Paul Kurlansky, MD
}

From the Division of Cardiac Surgery, Columbia University, New York, NY.

Disclosures: Author has nothing to disclose with regard to commercial support.

Received for publication May 31, 2019; revisions received June 13, 2019; accepted for publication June 14, 2019; available ahead of print Oct 17, 2019.

Address for reprints: Paul Kurlansky, MD, Black Building 210, 650 W 168th St, New York, NY 10032 (E-mail: Pk2245@cumc.columbia.edu).

J Thorac Cardiovasc Surg 2020;159:428-9

$0022-5223 / \$ 36.00$

Copyright (c) 2019 by The American Association for Thoracic Surgery

https://doi.org/10.1016/j.jtcvs.2019.06.129

How has the introduction of transcutaneous aortic valve replacement (TAVR) affected surgical aortic valve prosthesis choice? In this issue of the Journal, Tam and colleagues $^{1}$ address this issue in a carefully crafted and well-executed analysis of the Society of Thoracic Surgeons database. They demonstrate that the shift from mechanical to bioprosthetic valves preceded TAVR and actually slowed after its introduction. Perhaps counterintuitively, the rate of decline in mechanical valve selection in the earlier study years (2004-2011) was most pronounced in the youngest age group $(<60$ years). These findings leave unanswered the obvious question-what is it that accounts for the shift from mechanical to bioprosthetic valves? The phenomenon is international, ${ }^{2,3}$ yet it does not appear to be evidence driven. True, equivocal findings from registry data convinced the American guideline writing committee to update their IIa recommendation to choose either valve from the previous 60- to 70-year age range to the 50-70-year age range (level of evidence $\mathrm{B}$, nonrandomized). ${ }^{4,5}$ The Europeans still suggest a more modest $60-65$ range. ${ }^{6}$ Only one prospective randomized trial has addressed the issue in the past two decades (with equivocal findings). ${ }^{7}$ Recent metaanalyses suggest a slight survival benefit for mechanical valve selection in the 50-70 age range, with that benefit becoming clearer the younger the patient cohort. 8,9 Although studies vary in design and findings, none of the studies demonstrate a survival benefit for aortic bioprosthetic valves in younger patients. Yet none of these data appears to have impacted valve selection.

Advances in bioprosthetic valve design and tissue treatment have improved hemodynamics and valve longevity. Yet corresponding advances in mechanical valve design with reduced need for anticoagulation, ${ }^{10}$ as well as improved techniques for home international normalized ratio monitoring, do not appear to have had a similar effect. One might posit a concerted industry effort to promote models with planned obsolescence; however, trying to prove whether valve development has been driving or responding to market demand is a somewhat

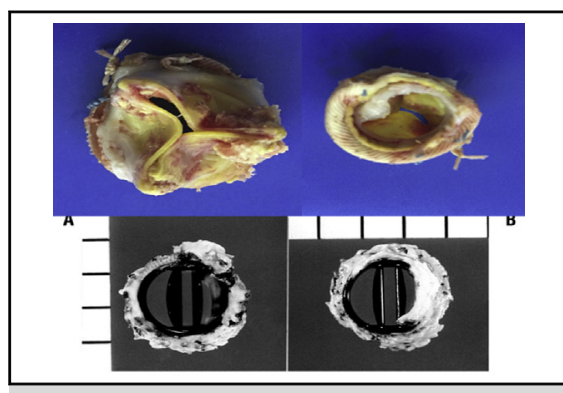

Valve pannus formation: biologic (top) and mechanical (bottom).

\section{Central Message}

The increasing preference for biologic rather than mechanical valve prostheses, even in younger patients, preceded the introduction of TAVR and highlights the need for a better alternative.

See Article page 416.

hopeless task. Leaving aside the many special circumstances - contraindications to anticoagulation, end-stage renal disease, anticipated pregnancy, high-risk occupations,

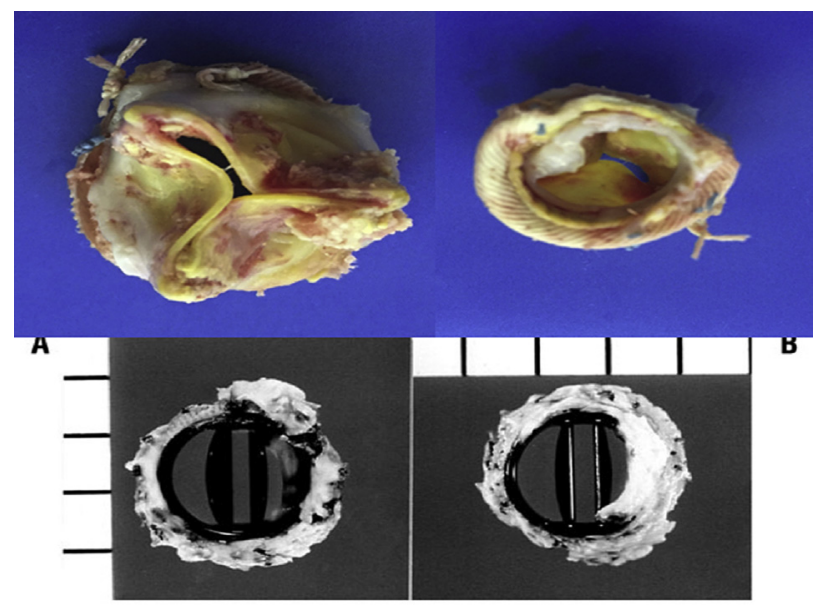

FIGURE 1. Valve pannus formation: biologic (upper panel) and mechanical (lower panel; A, bioprosthetic valve degeneration, B, mechanical valve pannus ingrowth). Upper panel reprinted with permission from: Kalra A, Rehman H, Ramchandani M, Barker C, Lawrie G, Ruel RM, et al. Early Trifecta valve failure: report of a cluster of cases from a tertiary care referral center. J Thorac Cardiovasc Surg. 2017;154:1235-40. Lower panel reprinted with permission from: Aoyagi S, Nishimi M, Kawano H, Tayama E, Fukunaga S, Hayashida N, et al. Obstruction of St Jude Medical valves in the aortic position. J Thorac Cardiovasc Surg. 2000;120:142-7. 
hyperparathyroidism - the most reasonable conclusion is that both physicians and patients are averse to warfarin. The hope that the more readily tolerated new oral anticoagulants and double antiplatelet therapy would provide adequate protection for newer mechanical valves has not been fulfilled. ${ }^{11,12}$ Interesting data suggest that physician fear of anticoagulation is out of proportion to clinical reality ${ }^{13}$ whereas patients are troubled by the continuous presence of sound and need for anticoagulant testing ${ }^{14}$-in short, nobody likes warfarin!

TAVR has provided a dramatic periprocedural advancement for patients with severe aortic stenosis. Information on valve longevity is evolving, however, and there may be an increased risk of thrombotic complications (ironically requiring anticoagulation). ${ }^{15}$ Even valve-in-valve TAVR, with concerns regarding coronary obstruction, patientprosthesis mismatch and pacemaker implantation, is certainly no long-term panacea. Indeed, we should not let the TAVR success story distract us from the real unanswered challenge- that of a biocompatible, durable, and hemodynamically favorable prosthetic heart valve (Figure 1). To meet that challenge, we will need to embrace emerging developments in biopolymers, 3-dimensional printing, molecular biology, and cell therapy.

\section{References}

1. Tam DY, Rocha RV, Wijeysundera HC, Austin PC, Dvir D, Fremes SE. Surgical valve selection in the era of transcatheter aortic valve replacement in the Society of Thoracic Surgeons database. J Cardiovasc Thorac Surg. 2020; 159:416-27.e8.

2. Dunning J, Gao H, Chambers J, Moat N, Murphy G, Pagano D, et al. Aortic valve surgery: marked increases in volume and significant decreases in mechanical valve use-an analysis of 41,227 patients over 5 years from the Society for Cardiothoracic Surgery in Great Britain and Ireland national database. J Thorac Cardiovasc Surg. 2011;142:776-82.e3.

3. Siregar S, de Heer F, Groenwold RH, Versteegh MI, Bekkers JA, Brinkman ES, et al. Trends and outcomes of valve surgery: 16-year results of Netherlands Cardiac Surgery National Database. Eur J Cardiothorac Surg. 2014;46:386-97; discussion 397.
4. Nishimura RA, Otto CM, Bonow RO, Carabello BA, Erwin JP III, Guyton RA, et al; ACC/AHA Task Force Members. 2014 AHA/ACC guideline for the management of patients with valvular heart disease: a report of the American College of Cardiology/American Heart Association task force on practice guidelines. Cir culation. 2014;129:e521-643. Errata in: Circulation. 2014;129:e651. Circulation. 2014;130:e120.

5. Nishimura RA, Otto CM, Bonow RO, Carabello BA, Erwin JP III, Fleisher LA, et al. 2017 AHA/ACC focused update of the 2014 AHA/ACC guideline for the management of patients with valvular heart disease: a report of the American College of Cardiology/American Heart Association task force on clinical practice guidelines. J Am Coll Cardiol. 2017;70:252-89.

6. Joint Task Force on the Management of Valvular Heart Disease of the European Society of Cardiology (ESC), European Association for Cardio-Thoracic Surgery (EACTS), Vananian A, Alfieri O, Andreotti F, Antunes MJ, et al. Guidelines on the management of valvular heart disease (version 2012). Eur Heart J. 2012; 33:2451-96.

7. Stassano P, Di Tommaso L, Monaco M, Iorio F, Pepino P, Spampinato N, et al. Aortic valve replacement: a prospective randomized evaluation of mechanical versus biological valves in patients ages 55 to 70 years. J Am Coll Cardiol. 2009;54:1862-8.

8. Diaz R, Hernanadez-Vaquero D, Alvarez-Cabo R, Avanzas P, Silva J, Moris C, et al. Long-term outcomes of mechanical versus biological aortic valve prosthesis: systematic review and meta-analysis. J Thorac Cardiovasc Surg. 2019; 158:706-14.e18.

9. Borger P, Charles EJ, Smith ED, Mehaffey JH, Hawkins RB, Kron IL, et al. Determining which prosthetic to use during aortic valve replacement in patients aged younger than 70 years: a systematic review of the literature. Heart Surg Forum. 2019;22:E070-81.

10. Puskas J, Gerdisch M, Nichols D, Quinn R, Anderson C, Rhenman B, et al; PROACT Investigators. Reduced anticoagulation after mechanical aortic valve replacement: interim results from the prospective randomized On-X valve anticoagulation clinical trial randomized Food and Drug Administration investigational device exemption trial. J Thorac Cardiovasc Surg. 2014;147:1202-10; discussion 1210-1.

11. Kumar V, Kelly S, Raizada A, Yee J, Anuwatworn A, Stys A, et al. Mechanical valve thrombosis on Rivaroxaban: are novel anticoagulants really an option? Methodist Debakey Cardiovasc J. 2017;13:73-5.

12. Puskas JD, Gerdisch M, Nichols D, Fermin L, Rhenman B, Kapoor D, et al; PROACT Investigators. Anticoagulation and antiplatelet strategies after On-X mechanical aortic valve replacement. J Am Coll Cardiol. 2018;71:2717-26.

13. Sen S, Dahlberg KW. Physician's fear of anticoagulant therapy in nonvalvular atrial fibrillation. Am J Med Sci. 2014;348:513-21.

14. Kottmaier M, Hettich I, Deutsch MA, Badiu C, Krane M, Lange R, et al. Quality of life and anxiety in younger patients after biological versus mechanical valve replacement. Thorac Cardiovasc Surg. 2017;65:198-205.

15. Makkar RR, Fontana G, Jilaihawi H, Chakravarty T, Kofoed KF, Backer OD, et al. Possible subclinical leaflet thrombosis in bioprosthetic aortic valves. $N$ Engl J Med. 2015;373:2015-24. 